\title{
Underemployment and Local Employment Dynamics: New Evidence*
}

\author{
Michaël Bonnal, Cristina Lira, and Samuel N. Addy ${ }^{+}$
}

Abstract. Workers in occupations that underutilize their experience, training, and skills are underemployed. Underemployment occurs for various reasons including productivity growth, spousal employment and income, family constraints, spatial restrictions, or personal preferences. Underemployment provides opportunities for selective job creation and economic growth. Using local employment dynamics (LED) and a statewide survey of the employed and nonworkers for 2004 and 2005, we examine the interaction between underemployment and LED. We show that poor local labor market conditions accentuate the perception of underemployment and lead to higher level of underemployment. Gender and ethnic differentials are also revealed in the characteristics of the underemployed.

Keywords: Underemployment, Regional Labor Markets

JEL Classifications: $J 21, R 12, R 23$

\section{INTRODUCTION}

Workers in occupations that underuse their experience, training, and skills are underemployed. These workers might be receiving salaries below what they believe they can earn; they might also be unsatisfied with their jobs or work fewer hours than they desire. It is generally assumed that underemployed workers could leave their current position for another job where their characteristics are better used. Thus, the underemployed are believed to present a significant pool of untapped labor because they are expected to respond to job opportunities that are better matches to their skills, training, and experience.

Although underemployment offers economic development potential, ${ }^{1}$ in terms of selective job creation and economic growth, there is a lack of data about such potential being realized, in part because no official U.S. government statistics are currently available on the underemployed. Still, the Bureau of Labor Statistics (BLS) does provide an array of measures of labor underutilization. Labor force data is often limited to what is available from government sources and mainly provides information on the employed and the unemployed. While valuable, such information may not be complete from the perspective of employers and the underemployed. New or expanding employers are interested in "underemployment" as well because incumbent workers are excellent candidates for more intensive employment. In fact,

\footnotetext{
* The authors thank Tony Barkune, Dean Jolliffe, Leila Pratt, and two anonymous referees for helpful comments. For project funding, the authors acknowledge support from Alabama Department of Economic and Community Affairs, Alabama Department of Industrial Relations, Alabama Department of Postsecondary Education, Alabama Industrial Development Training, Alabama Office of Workforce Development, Alabama Power Company, and The University of Alabama.

${ }^{+}$Bonnal is Assistant Professor of Economics at the University of Tennessee at Chattanooga. Addy is Director and Associate Research Economist at the Center for Business \& Economic Research of the University of Alabama. Lira received her Ph.D. in Economics at the University of Alabama.

Contact author: Michaël Bonnal, Department of Economics, The University of Tennessee at Chattanooga, 615 McCallie Avenue, Chattanooga, TN 37403. E-mail: michael-bonnal@utc.edu.

1 Attempts at measuring this economic potential can be made. However, this is extremely difficult because of uncertainty regarding the additional income that the underemployed can bring to an area.
} 
many prospective employers often do not consider unemployed workers as potential job candidates. Southern states, in their efforts to attract new investment and jobs (following the new non-union automobile plants in Kentucky and Alabama) have commissioned surveys of "underemployment" in the labor force to better estimate the "available labor pool" for prospective high-wage employers. The University of Alabama's Center for Business and Economic Research (CBER) was engaged to prepare "state of the workforce" reports on the state, its counties, and workforce development regions, which included a rather large survey of Alabama households (almost 19,000 respondents) to provide numerical estimates of the available labor pool within the state.

Underemployment occurs for various personal reasons, including spousal employment and income, family constraints, spatial restrictions, or other personal preferences. Another cause of underemployment that is not often considered is productivity growth: workers become underemployed because they learn to do their jobs better and faster. In addition, underemployment can be unique to certain areas because certain features of the local labor market intensify selected personal characteristics to induce underemployment.

This paper examines the relationship between underemployment, characteristics of the labor force, and local labor market conditions using the survey developed by CBER (see Section 3 and Addy et al., 2005, 2006 for more details) and Local Employment Dynamics (LED) data resulting from an inter-agency collaboration. It also relies on data from both the U.S. Census Bureau and the BLS. In addition to demographic information, the underemployment survey provides unique information about employment status, nature of employment, willingness to work full-time if currently working part-time, number of jobs, commute time and distance, occupation and industry, job tenure, income, job fitness, income incentive to leave current job for a better one, incremental commute time and distance, and job search activity. Figure 1 lists the specific questions on the survey instrument. ${ }^{2}$ Moreover, the design of the survey enables a measure of underemployment by productivity growth since it lets the respondents declare if they believe they are underemployed or not. The combination of our survey data and the LED data yield a more complete labor profile for the region, which is an innovation with respect to other currently available data. The result is a unique set of information that can be of great potential value to community and regional leaders, educators, planners, policy makers, economic developers, and prospective employers. In addition, these data enable the study of the relationship between underemployment and both characteristics of the labor force and local labor market conditions, the focus of this paper. As a result, we show that poor local labor market conditions accentuate the perception of underemployment and lead to higher levels of underemployment. We also reveal the importance of gender and ethnic differentials in the characteristics of the underemployed.

The underemployed are a subset of the sample of employed workers. Since having a job interferes with the quality of a job search, it is likely that self-selection into the group of workers influences the characteristics of the underemployed. That is, there undoubtedly are unobserved factors that influence both the decision to participate in the labor market and the perception of underemployment. In order to account for this potential selection bias, this paper employs a variant of the Heckman selection model.

\footnotetext{
${ }^{2}$ This questionnaire was designed specifically for estimating underemployment and was used to survey the labor force in Alabama by county.
} 
The paper is organized as follows. First, we give some theoretical and empirical background to our study. Then we present the survey on underemployment and our empirical methodology. Finally, we discuss our empirical results and conclude with the contributions of our study.

\section{THEORETICAL AND EMPIRICAL UNDERPINNINGS}

BLS does not currently compile any official statistics on underemployment. $^{3}$ Nonetheless, underemployment rates have been estimated for some states and communities. For example, The Pathfinders - a consulting company based in Dallas, Texas-estimate underemployment for certain areas in Alabama. Underemployment rates have been estimated for Kentucky and Nebraska (see Bollinger, Coomes, and Berger, 2003; NWD, 2002).

Because underemployment means different things to different people, the definition of underemployment in any study must be explicitly stated to enable proper understanding and use of its results. Underemployment has been defined very narrowly in some cases simply to account for a surplus of high-skill labor (see for example Moore, 2005). However, the International Labor Organization (ILO) uses a broader perspective that recognizes underemployment as the underutilization of the productive capacity of everyone who is employed, not just the highlyskilled. Despite this recognition, the ILO provides a definition for a somewhat restrictive timerelated concept of underemployment, one used by several countries. ${ }^{4}$ According to the ILO's time-related definition, the underemployed include all employed persons who are willing to work additional hours, ${ }^{5}$ are available to work additional hours within a specified subsequent period, and work less than a specified working-time threshold. ${ }^{6}$

The ILO time-related definition, while superior, omits an important cause of underemployment-labor productivity growth. Workers can become underemployed as their productivity rises because they can do more work in the same amount of time. One way to incorporate the effect of labor productivity growth in a measure of underemployment is to let respondents declare whether or not they are underemployed, since respondents are probably best equipped to compare their job conditions with their personal characteristics. This approach, also used by The Pathfinders (Bollinger, Coomes, and Berger, 2003; NWD, 2002), is favored in this paper.

In addition to productivity growth, as discussed above, there are many factors that affect the probability of being underemployed. For example, spousal employment and income, extended family relationships or responsibilities may limit workers' ability to find jobs that make full use of the value of their education, training, skills, and experience. Geographic immobility due to family constraints or personal preferences may be another factor contributing to underemployment (van Ham et al., 2001). The various contributing factors combined with economic, social, and geographic characteristics make underemployment unique to specific

\footnotetext{
${ }^{3}$ The reason given for this, according to the BLS, is a difficulty of developing an objective set of criteria which could be readily used in a monthly household survey. This difficulty undoubtedly comes from a preference to indirectly estimate the underemployment rate from a survey that does not ask respondents directly whether or not they are underemployed. For example, unemployment is estimated indirectly.

${ }^{4}$ See ILO (1998) for details.

${ }^{5}$ It is recommended that those who have actively sought to work additional hours be distinguished from those who have not.

${ }^{6}$ This threshold is determined by the country. For example, the United States uses the 35-hour reference week suggested by the BLS as the boundary between full-time and part-time work.
} 
areas. Indeed, demographic and socio-economic characteristics of the underemployed may be very different among communities. For this reason, information from the LED data can add significantly to the explanation of the level of underemployment in a certain region.

Family income and wage are important factors in determining the probability of being underemployed. In particular, wage is the most direct variable that is used to compare the costs and benefits of searching for a new job since, through consumption, it indirectly affects the utility of individuals. Other personal and structural characteristics such as gender, educational attainment, or spatial restrictions are discussed in the theoretical and empirical human capital literature to explain costs and benefits of different work positions and underemployment.

According to the home-economy literature, women (especially married and/or with children) have to reconcile caring and working activities and for this reason are less able to participate in the labor market (Becker, 1991). The findings on this topic are generally in agreement and have led to a particular field in the literature that investigates the structural characteristics and spatial restrictions which raise some women's reservation wages and, thereby, worsen their position in the formal labor market (see van Ham et al., 2001; van Ham and Büchel, 2006; and Hanson and Pratt, 1991). This lack of ability to fully participate in the labor market may make some women more likely to consider themselves underemployed.

The relationship between educational attainment and underemployment finds its roots in the theory of human capital (Becker, 1962). The educational level of workers is important in evaluating the match between skills acquired during the educational process and the ones requested on the job (Hersch, 1991). Any mismatch between these skills and the job attained generates underemployment. The higher the level of education the wider the set of possible work choices and the lower the probability of being underemployed. However, if the job market does not provide many jobs that require high levels of education, a given highly educated worker is likely to perceive that his or her probability of being underemployed is rather high. The relationship between the level of education, skill mismatches, and underemployment could be less direct, however. Skill mismatches are found to be better predictors of job satisfaction-one of the causes of underemployment - than are educational mismatches (Allen and van der Vellen, 2001). The authors show that the experience acquired during one's working life could be more important in explaining underemployment than is achieved formal education itself. ${ }^{7}$ Some studies also develop measures of match between job opportunities and skills of workers in an area (Immergluck, 1998) that appear to explain labor force participation rates. An example of these measures is the nearby jobs/labor-force ratio, i.e., the ratio between the number of low and moderate skilled jobs and the number of individuals in the labor force who live within two miles of the zone and who currently work in the low and moderate skilled jobs. This and similar measures are found to have significant association with area employment rates.

An additional reason for mismatch and lack of job fit can be found in the theory of the "tied mover/tied stayer." Mincer (1978) explores the effects of family ties on migration decisions and finds that family ties add friction to migration propensities and, thereby, reduce women's employment and earnings while increasing the employment and earnings of men. The spatial mismatch problem is a special case of the resource misallocations that can generate underemployment (Kain, 1968; Simpson, 1992). In this case, spatial restrictions, usually

\footnotetext{
${ }^{7}$ While this is in contrast with the assignment theory (Sattinger, 1993), it follows a seminal theoretical model about job turnover and matching between skills and job position (Jovanovic, 1979).
} 
measured by the monetary cost of migration or commuting, reduce the set of opportunities available or considered by individuals (van Ham et al., 2001; Hanson and Pratt, 1992). A common finding in this literature is that higher levels of education are associated with a greater willingness to commute and thus a higher probability of solving spatial restrictions. Males, younger workers, and those with more experience also seem more likely to overcome spatial restrictions. Still, socio-economic indicators such as wages and educational level tend to be more important than spatial restrictions in explaining one's willingness to invest in their commute (McQuaid, Greig, and Adams, 2001). For example, belonging to a minority group combined with higher levels of education significantly explain more of the local employment rate than do spatial restrictions (Immergluck, 1998).

The argument for spatial restrictions is linked to the structure of the local economy. For example, job search activity can be more intense if there is local unemployment or underemployment. In fact, the decision to leave a job that does not fit well with the worker's skills could be mitigated by a local economy with few job opportunities. This phenomenon is called the "discouraged worker effect" and was developed by Dernburg and Strand (1966) and Renaud and Phan (1975). The importance of the discouraged worker effect is underlined in the design of policies targeted to promote local employment (van Ham et al., 2001; McQuaid, Greig, and Adams, 2001). Some studies add the discouraged worker effect into their analysis as an indicator of job search activity (van Ham and Büchel, 2006).

The introduction of characteristics of the local labor market conditions such as the unemployment rate, job turnover, or the average monthly earnings of workers provides a more complete framework of the labor market and helps understand the mechanisms underlying underemployment (van der Lippe and van Dijk, 2002). One innovation of this paper is that we simultaneously measure the effects of some local labor market conditions and characteristics of the underemployed. Identifying the role of the labor market in involuntary underemployment is essential. About half of those in the survey who say that they are underemployed cite "lack of job opportunities" as a reason (see Table 1). Undoubtedly, much of this occurs in a local labor market context; urban labor markets are thicker-provide more opportunities - than are rural labor markets. Indeed, rural labor markets are often hampered by geographical isolation and long-standing cultural separation among racial and ethnic groups within communities, further impeding the efficient function of the local labor market.

\section{DESCRIPTION OF THE SURVEY AND EMPIRICAL METHODOLOGY}

The database used in our estimations is drawn both from the surveys gathered by the University of Alabama's Center for Business and Economic Research (CBER) and from the Local Employment Dynamics available through the U.S. Census Bureau. The LED data are derived from state administrative records and basic demographic and labor information from the U.S. Census Bureau and the BLS. The CBER survey was undertaken in two waves, starting in 2004 and ending in 2005. It was developed via a telephone survey of about 19,000 respondents almost half of which were employed workers.

To probe for underemployment, respondents were asked questions about employment status, nature of employment, willingness to work full-time if part-time, number of jobs, commute time and distance, occupation and industry, job tenure, income, job fitness, income incentive to leave current job for a better one, incremental commute time and distance, and job search activity. The BLS 35-hour week threshold was used to distinguish between full-time and 
part-time for respondents who were not sure of their time status. Demographic information was then collected to complete the interview.

The survey instrument is presented in Figure 1. The measurement of mismatch or, more precisely, underemployment is based on the respondent's opinion. Respondents are asked for their opinion on whether or not they are underemployed as well as for the reasons they identify that status. Therefore, underemployment is self-reported. Below is an extract from the survey questionnaire:

\begin{abstract}
The next few questions relate to underemployment. A person can think of himself or herself as underemployed for various reasons (e.g., if you can take on additional challenges or responsibilities for the same or better pay. You may also be underemployed by choice because your spouse has a really good job and you want to focus on the children, home-schooling, the family, or other personal/family matters).
\end{abstract}

20. Question: Do you think you are underemployed in your current job?

An employed respondent is expected to claim to be underemployed if his or her education, training, skills, and experience are not fully utilized in his or her job. The design of the survey also permitted the inclusion of instruments to validate and confirm that the response to the above question was an accurate reflection of underemployment (see Figure 1). A self-reported measure of underemployment could be criticized for not being objective. If we could have the precise occupation and industry of each respondent, then we could assess the functional work requirements of each respondent's job and compare them with their educational attainment. However, information about occupation and industry collected in the survey are not detailed enough to establish such a comparison. "Respondent opinions" are sometimes viewed skeptically. The current research is able to mitigate these problems since the survey contains three additional questions that help validate the construct of the underemployment measure, guaranteeing that we are not dealing with "disgruntled workers." 8

The sample frame set-up showed that 100 completed responses per county, except for urban Jefferson and Mobile counties where 500 would be required for each, would be sufficient. Thus, the total expected sample size for the two waves of surveys was 15,000. Specific county targets for number of employed respondents were set based on county population in year 2000 and economic activity in general. Specifically, we considered the most recent economic structure using data from the U.S. Bureau of Economic Analysis. This meant a total minimum number of 8,280 employed respondents were required statewide. Achieving this target while also ensuring a randomly selected and representative sample by county resulted in the collection of 18,927 completed survey responses. This is a third more than the 15,000 expected initially. The expansion was necessary due to the unanticipated large share of responses from nonworkers. A bit more than half of the completed responses were from employed people. About 12.4 percent of respondents (a count of 2,350) declared that they were underemployed. Table 1 presents descriptive summary statistics of the 2004 underemployment survey.

\footnotetext{
${ }^{8}$ For a discussion about potential skepticisms associated with respondent opinions in surveys, see for example Bertrand and Mullainathan (2001).
} 


\title{
FIGURE 1: Questions on the Underemployment Survey Instrument
}

\author{
General \\ 1. Do you currently work anywhere for pay? [Go to \#21 if answer is "no"] \\ 2. Do you work for pay at more than one job? \\ 3. On average, how many hours a week do you work at your job(s) [primary job]? The primary job is the one \\ you spend most of your working time at. \\ 4. Would you say that you work 35 or more hours a week? \\ 5. Would you like a full time job? \\ 6. How long have you been working in your current job [primary job]? \\ 7. On average, how long does it take you to get to [your workplace] the workplace for your primary job? \\ 8. How many miles from your home is your workplace [the workplace for your primary job]? \\ 9. What is your occupation [at your primary job]? \\ 10. Including the time before you got your [current job | primary job], how many years have you worked in this \\ occupation? \\ 11. What industry do you work in at your [current job | primary job]? \\ 12. For statistical purposes only, was your income last month? (a) Less than $\$ 500$ (b) $\$ 500-\$ 1,000$ (c) $\$ 1,000$ - \\ $\$ 2,000$ (d) $\$ 2,000-\$ 3,000$ (e) $\$ 3,000-\$ 4,000$ (f) $\$ 4,000-\$ 6,000$ (g) More than $\$ 6,000$ ?
}

\section{Fitness}

Please consider your education and training, skills, and experience for the next couple of questions.

13. Does your [current job | primary job] fit well with your education and training, skills, and experience?

14. Are you qualified for a better job than the [one / primary job] you have now?

15. Which of the following reasons make you qualified for a better job? (Please respond to all that apply)

(a) Education and training (b) Skills (c) Experience

16. How much more would a new job need to pay for you to be willing to leave your [current job | primary job]? (a) $0-5 \%$, (b) $5-15 \%$ (c) $15-30 \%$ (d) $30-50 \%$ (e) More than $50 \%$

17. How much farther are you willing to commute for a new job that paid that much more? (a) 0-10 miles (b) 1020 miles (c) More than 20 miles

18. How much more time are you willing to spend commuting one-way for such a job? (a) 0-10 minutes (b) 1020 minutes (c) More than 20 minutes

19. Have you looked for a better job in the past 3 months?

\section{Underemployment}

The next few questions relate to underemployment. A person can think of himself or herself as underemployed for various reasons (e.g., if you can take on additional challenges or responsibilities for the same or better pay. You may also be underemployed by choice because your spouse has a really good job and you want to focus on the children, home-schooling, the family, or other personal/family matters).

20. Do you think you are underemployed in your current job?

\section{Reasons for being underemployed or unemployed}

21. Which of the following reasons would you say make you underemployed? (Please respond to all that apply) (a) A lack of job opportunities in your area (b) The low wages at the available jobs (c) You live too far from [jobs | BETTER jobs] (d) You are in school or undergoing training (e) Your spouse or partner has a really good job (f) You are retired or because of social security limitations (g) Disability or other health concerns

(h) Child care responsibilities (i) You take care of someone other than a child (j)Other family or personal obligations

Demographics - Ask all respondents

22. Are you currently married?

23. Would you please confirm whether you are male or female?

24. What is your age?

25. What is the last grade of school you completed?

(a) Some high school or less, no diploma (b) High School /GED (c) Some college, no degree (d) Jr.

College/trade school, associate degree (e) Four-year college graduate, Bachelor's degree (f)

Postgraduate/Masters etc.

26. Would you say you are Hispanic or non-Hispanic?

27. Would you say you are [RACE CATEGORIES]?

28. What [Alabama] county do you live in? 
TABLE 1. Alabama Underemployment Survey Results (Percent)

\begin{tabular}{|c|c|c|}
\hline General & Employed & "Underemployed \\
\hline Percent of adults that are working full-time & 78.1 & 70.1 \\
\hline Percent of part-timers who would like to work full-time & 29.8 & 45.3 \\
\hline Percent of workers with more than one job & 9.3 & 9.6 \\
\hline $\begin{array}{r}\text { Less than } 20 \text { minutes } \\
20 \text { to } 40 \text { minutes } \\
40 \text { minutes to an hour } \\
\text { More than an hour }\end{array}$ & $\begin{array}{r}57.3 \\
27.0 \\
9.3 \\
1.7\end{array}$ & $\begin{array}{r}55.8 \\
28.4 \\
9.8 \\
3.1\end{array}$ \\
\hline $\begin{array}{r}\text { Less than } 10 \text { miles } \\
10 \text { to } 25 \text { miles } \\
25 \text { to } 45 \text { miles } \\
\text { More than } 45 \text { miles }\end{array}$ & $\begin{array}{r}45.9 \\
29.5 \\
13.7 \\
6.1\end{array}$ & $\begin{array}{r}43.3 \\
31.4 \\
13.9 \\
6.3\end{array}$ \\
\hline $\begin{array}{r}\text { Farmer/Farming/Hunting/Fishing } \\
\text { Manager/Teacher/Professional } \\
\text { Administrative Support/Clerical } \\
\text { Laborer } \\
\text { Technician/Machine Operator/Assembler/Inspector } \\
\text { Transportation Operator } \\
\text { Retail/Wholesale Salesperson } \\
\text { Police/Army } \\
\text { Mechanic/Repairer } \\
\text { Doctor/Vet } \\
\text { Nurse } \\
\text { Hotel/Restaurant/House Help } \\
\text { Student } \\
\text { Other and D/K or N/A }\end{array}$ & $\begin{array}{r}1.6 \\
18.2 \\
10.9 \\
5.7 \\
11.3 \\
2.7 \\
6.1 \\
1.3 \\
1.3 \\
0.6 \\
6.1 \\
4.3 \\
0.3 \\
29.4\end{array}$ & $\begin{array}{r}0.9 \\
16.0 \\
9.9 \\
6.3 \\
12.2 \\
2.9 \\
7.5 \\
1.7 \\
1.3 \\
0.3 \\
6.0 \\
5.3 \\
0.7 \\
28.5\end{array}$ \\
\hline $\begin{array}{rr}\text { Number of years at current/primary job } & \text { Less than a year } \\
1 \text { to } 3 \text { years } \\
3 \text { to } 5 \text { years } \\
5 \text { to } 10 \text { years } \\
10 \text { to } 20 \text { years } \\
\text { More than } 20 \text { years }\end{array}$ & $\begin{array}{r}14.3 \\
10.1 \\
9.7 \\
15.8 \\
24.8 \\
24.4\end{array}$ & $\begin{array}{l}17.4 \\
11.3 \\
10.0 \\
17.5 \\
24.4 \\
18.7\end{array}$ \\
\hline $\begin{array}{r}\text { Manufacturing } \\
\text { Mining } \\
\text { Construction } \\
\text { Finance, Insurance or Real Estate } \\
\text { Local Government } \\
\text { State Government } \\
\text { Federal Government } \\
\text { Transportation, Communication or Public Utilities } \\
\text { Trante or Retail Trade } \\
\text { Farming, Hunting, Fishing, Landscaping, or Other Agricultural } \\
\text { Services for Healthcare, Business, Hotel, Restaurant, Household }\end{array}$ & $\begin{array}{r}11.9 \\
0.5 \\
5.2 \\
8.5 \\
3.9 \\
4.5 \\
8.1 \\
3.0 \\
6.4 \\
3.1 \\
29.2\end{array}$ & $\begin{array}{r}13.0 \\
0.6 \\
4.9 \\
11.1 \\
3.0 \\
4.7 \\
8.2 \\
2.2 \\
5.5 \\
3.1 \\
28.7\end{array}$ \\
\hline $\begin{array}{r}\text { Less than } \$ 500 \\
\$ 500 \text { up to } \$ 1,000 \\
\$ 1,000 \text { up to } \$ 2,000 \\
\$ 2,000 \text { up to } \$ 3,000 \\
\$ 3,000 \text { up to } \$ 4,000 \\
\$ 4,000 \text { up to } \$ 6,000 \\
\text { More than } \$ 6,000\end{array}$ & $\begin{array}{r}5.6 \\
12.6 \\
24.2 \\
18.3 \\
9.6 \\
7.0 \\
5.7\end{array}$ & $\begin{array}{r}10.8 \\
18.4 \\
29.3 \\
16.6 \\
7.4 \\
4.1 \\
3.2\end{array}$ \\
\hline
\end{tabular}


TABLE 1. Alabama Underemployment Survey Results (Percent, continued)

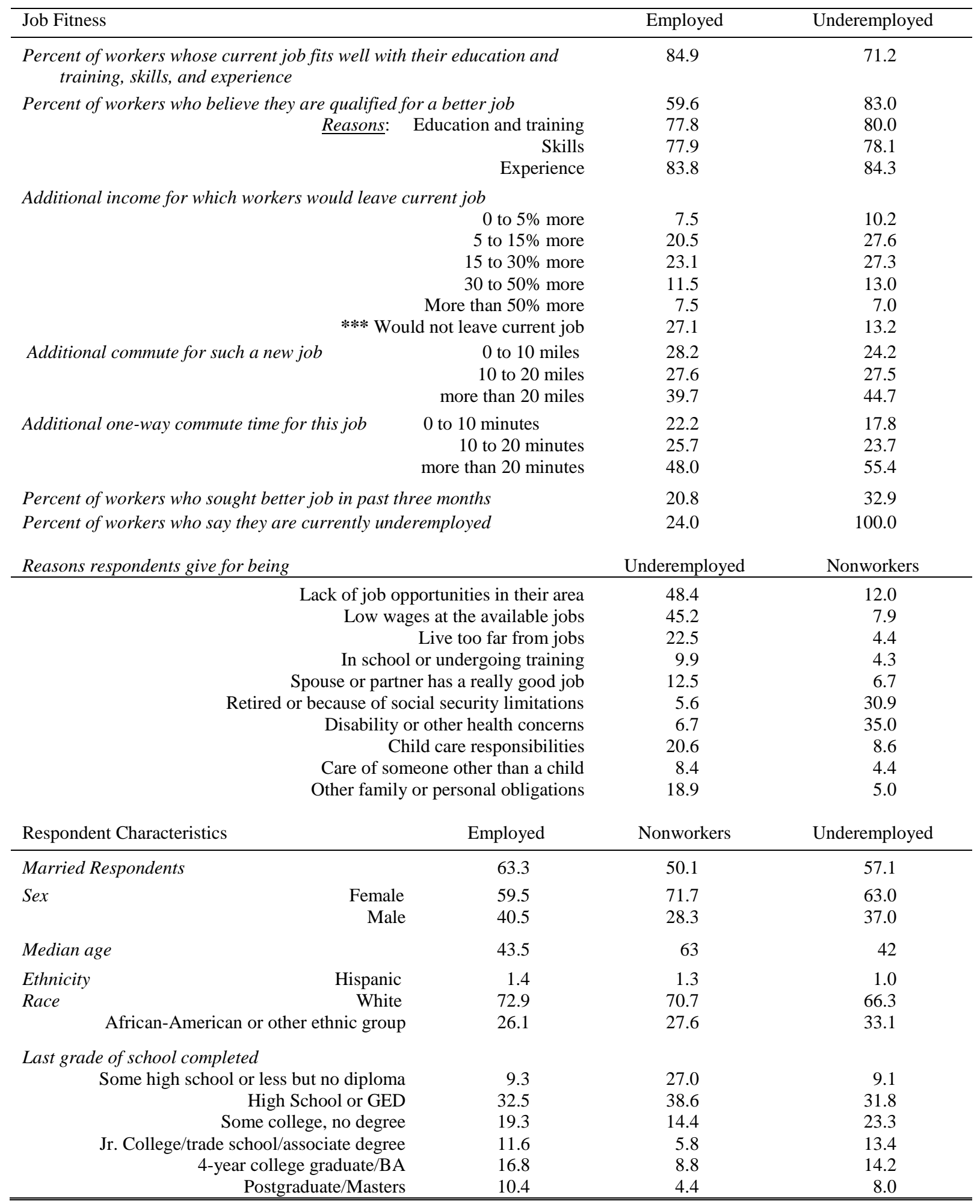

Note: Responses to the questions on occupation and industry should only be used for making comparisons between the employed and the underemployed and not for indicating worker distribution by occupation or industry. 
Survey results showed that Alabama's underemployment rate was 24 percent in 2004. This represents 495,000 potential workers in addition to the 109,000 unemployed, for a total available labor pool of 604,000 . For every unemployed person there were roughly five underemployed in the state. In 2005, the underemployment rate was 25.2 percent. $^{9}$ This means that about 542,000 employed Alabama residents were underemployed. Adding the unemployed gives a total available labor pool of about 615,000 for the state. This pool is more than eight times the number of unemployed and is a more realistic measure of the available labor in Alabama. It is important to note, however, that an underemployed worker is not a full-time equivalent (FTE) available worker in the manner that an unemployed person might be because the hiring of an underemployed worker in a better matching or higher paying job also is a loss of a worker to his or her previous employer. Thus the available labor pool is merely a count of people who are willing to work more productively and not of the number of FTE persons available to work.

The variables used in this paper are described in Table 2, with their respective descriptive statistics listed in Table 3. In addition to the individual and local underemployment variables, we include Local Employment Dynamics ${ }^{10}$ measures, which give information about local labor market conditions such as unemployment rate, turnover rate, or average monthly earnings of employees. Finally, individual characteristics such as age, education, ethnicity, and gender complete the set of control variables. These specific explanatory variables will be stated again with their name identifiers when we present the model equations at the end of this section.

Analyzing underemployment while restricting the sample to employed workers only could lead to biased results. The present study accounts for this sample selection bias by employing a variant of Heckman's (1979) two-step selection model. In the first step, those in the active labor force constitute identifying whether individuals are employed or unemployed. Any variables related to job characteristics are not included in this equation (selection model), because they perfectly identify employed workers since unemployed workers, by definition, have no job to characterize. In the second step, the probability of being underemployed is analyzed only for employed workers in the sample. Since the dependent variables in both the selection (employed or not) and main (underemployed or not) equations are binary, we employ a bivariate probit model with sample selection via maximum-likelihood estimation, following van de Ven and van Pragg (1981). The critical link between the two equations is the correlation of the error terms of the main equation and the selection equation. The presence of correlation is determined by a significant Wald test.

This two-step model formulation requires that at least some of the explanatory variables in the selection equation are different from the explanatory variables in the outcome equation for the model to be properly identified. To that end, it is required to include in the selection equation at least one instrument that affects the decision to participate in the labor force but not the probability of being underemployed. This is always not an easy task. Most factors influence both the probability of being employed and the probability of being underemployed. We use the

\footnotetext{
${ }^{9}$ There could be a natural underemployment rate, analogous to the natural unemployment rate. Schaeffer (1985) illustrates that workers deliberately choose jobs because of their potential to add to their human capital, so as to become qualified for another job up the career ladder. In this process, there would be times when workers will be underemployed until they move to this next job.

${ }^{10}$ The Local Employment Dynamics were pooled at the county level, by year, age range, and gender.
} 
TABLE 2: Descriptions of Study Variables

\begin{tabular}{|c|c|}
\hline Variables & Definition \\
\hline \multicolumn{2}{|l|}{ Dependent Variables } \\
\hline Underemployment & $\begin{array}{l}\text { Underemployment takes the value of one when the individuals believe they are } \\
\text { underemployed in their current job, and zero otherwise. }\end{array}$ \\
\hline Employment & $\begin{array}{l}\text { Employment takes the value of one when the individuals currently work for pay, } \\
\text { and zero otherwise. }\end{array}$ \\
\hline \multicolumn{2}{|l|}{ LED Variables } \\
\hline Area Worker & Average monthly earnings of employees in the county where the individual resides. \\
\hline Earnings & $\begin{array}{l}\text { It is given by the total quarterly earnings of all full-quarter employees divided by } \\
\text { the number of full-quarter employees, divided by } 3 \text { (Average: last quarter } 04 \text { or } 05 \\
\text { if year is } 04 \text { or } 05+3 \text { Prior quarters). }\end{array}$ \\
\hline Turnover & $\begin{array}{l}\text { Turnover is the rate at which an employer gains and loses employees. It is equal to } \\
(1 / 2) * \text { (full-quarter accessions + full-quarter separations) / employment stable jobs } \\
\text { (Average: last quarter } 04 \text { or } 05 \text { if year is } 04 \text { or } 05+3 \text { Prior quarters). }\end{array}$ \\
\hline Unemployment & $\begin{array}{l}\text { Unemployment is the unemployment rate for either } 2004 \text { or } 2005 \text { in the county } \\
\text { where the individual resides. }\end{array}$ \\
\hline \multicolumn{2}{|l|}{ Other Variables } \\
\hline Afro-American & $\begin{array}{l}\text { Afro-American takes the value of one when the individual is African-American, and } \\
\text { zero otherwise. }\end{array}$ \\
\hline Age & Age of the individual. \\
\hline Education & $\begin{array}{l}\text { Education is the last grade of school completed by the individual. It is } 1 \text { for some } \\
\text { high school or less but no diploma; } 2 \text { for high school or GED; } 3 \text { for some college, } \\
\text { no degree; } 4 \text { for Jr. college, trade school, associate degree; } 5 \text { for } 4 \text {-year college } \\
\text { graduate, B.A.; and } 6 \text { for postgraduate, masters. }\end{array}$ \\
\hline Female & Female takes the value of one when the individual is a female, and zero otherwise. \\
\hline Married & $\begin{array}{l}\text { Married takes the value of one when the individual is currently married, and zero } \\
\text { otherwise. }\end{array}$ \\
\hline Local UnderE & $\begin{array}{l}\text { Local UnderE is the number of underemployed expressed as a percentage of the } \\
\text { employed for either } 2004 \text { or } 2005 \text { in the county where the individual resides. }\end{array}$ \\
\hline
\end{tabular}

Sources: Except for LED variables, variables are from the surveys collected by the University of Alabama's Center for Business and Economic Research. The LED data are derived from state administrative records and demographic and labor information from the Census Bureau and the BLS (see http://lehd.did.census.gov/led/gdocs/Metadata4_QWI.htm).

TABLE 3: Descriptive Statistics for Key Study Variables

\begin{tabular}{lrrrrr}
\hline \hline Variables & \multicolumn{1}{c}{$\mathbf{n}$} & \multicolumn{1}{c}{ Mean } & Std. Dev. & \multicolumn{1}{c}{ Min } & \multicolumn{1}{c}{ Max } \\
\hline Afro-American & 18,505 & 0.242 & 0.429 & 0 & 1 \\
Age & 18,657 & 51.736 & 17.305 & 18 & 65 \\
Area Worker Earnings & 18,656 & $\$ 2,293$ & $\$ 861$ & $\$ 432$ & $\$ 5,374$ \\
Education & 18,839 & 2.891 & 1.533 & 1 & 6 \\
Employment & 18,927 & 0.501 & 0.500 & 0 & 1 \\
Female & 18,920 & 0.657 & 0.475 & 0 & 1 \\
Local UnderE & 18,927 & 0.246 & 0.051 & $6.30 \%$ & $38.60 \%$ \\
Married & 18,918 & 0.585 & 0.493 & 0 & 1 \\
Turnover & 18,656 & 0.091 & 0.044 & $3 \%$ & $39 \%$ \\
Underemployment & 9,482 & 0.248 & 0.432 & 0 & 1 \\
Unemployment & 18,927 & 0.053 & 0.016 & $2.56 \%$ & $10.93 \%$ \\
\hline \hline
\end{tabular}


area's unemployment rate as our instrument, because area unemployment more clearly affects the probability of being employed directly and far less clearly the probability of being underemployed, at least in any direct sense. In fact, only when unemployment is extraordinarily far from its "natural" rate or extraordinarily persistent should we expect a strong relationship between an area's rates of unemployment and underemployment. Since Alabama's statewide unemployment rate was 5.1 percent for 2004 and 3.9 percent in $2005,{ }^{11}$ we can safely assume that the unemployment rate was very close to its long-run natural rate. Moreover, the correlation coefficient between the rates of unemployment and underemployment is small (.0251). relationship:

In the bivariate probit model with sample selection, we assume the following

$$
\text { underemployment }{ }_{j}^{*}=\beta X_{j}+u_{1 j}
$$

such that we observe only the binary outcome

$$
\text { underemployment }_{j}^{\text {probit }}=\left(\text { underemployment }_{j}^{*}>0\right)
$$

The dependent variable, underemployment, is not always observed; and the dependent variable for observation $j$ is observed if

$$
\text { employment }_{j}^{\text {select }}=\left(Z_{j} \gamma+u_{2 j}>0\right)
$$

where $X_{j}$ includes Married, Female, Age, Education, Afro-American, Local UnderE, Turnover, and Area Worker Earnings (see Table 2 for their definition) and $Z_{j}$ includes all the variables in $X_{j}$ plus the instrument variable Unemployment; and where

$$
\begin{gathered}
u_{1} \sim N(0,1) \\
u_{2} \sim N(0,1) \\
\operatorname{corr}\left(u_{1}, u_{2}\right)=\rho .
\end{gathered}
$$

When $\rho \neq 0$, biased estimates will result from standard probit techniques of Equation (1). The probit model with sample selection provides consistent, asymptotically efficient estimates for all the parameters in the model (StataCorp, 2007). As mentioned above, we add Unemployment in the selection equation (Equation (3)) as an instrumental variable, so this instrument is not included in Equation (2). ${ }^{12}$

From the theoretical background presented in Section 2, we expect the coefficients for the variables Married, Education, and Area Worker Earnings to be negative. That is, being married, having more education, and living in an area with comparatively high-levels of labor income per worker should reduce a worker's propensity to be underemployed. The signs for the coefficients on Female, Age, Afro-American, Local UnderE, and Turnover are expected to be positive. That is, due to occupational and wage discrimination we expect female and/or African-American workers to have a higher chance of being underemployed than a male and/or white worker. The effects of general local labor market conditions are indeterminate: for example, in areas that are faring below average, workers might feel underemployed due to a lack of solid job opportunities or they might simply consider themselves to be fully employed due to a sense of gratitude from at least having a stable job. Still, in areas with high job turnover and underemployment rates,

\footnotetext{
${ }^{11}$ Source: Bureau of Labor Statistics. The nationwide rate of unemployment was 5.5 percent in 2004 and 5.1 percent in 2005.

${ }^{12}$ If $Z_{j} \not \supset X_{j}$, then our model would only be identified by functional form and the estimated coefficients would have no structural interpretation.
} 
people who are working should be more likely to feel underemployed. The following discussion details the variables included in our estimation and the expected directions of their effects.

\section{INTERPRETATION OF ESTIMATION RESULTS}

Table 4 shows the parameter estimates of the bivariate probit model with sample selection. First, the Wald test of independence of equations (2) and (3) shows that the coefficient $\rho(-0.838)$ is significantly different from zero, indicating that there is a correlation between the errors terms of the employment equation and the underemployment equation. This correlation reveals that unobserved respondent characteristics influence both the probability of being employed and the probability of being underemployed. Thus we need to correct for selection bias; the choice of estimation method addresses this issue. Moreover, some job-related characteristics were only collected for the subset of employed workers (such as experience, job fitness or worker's qualifications) and cannot be used in the current estimation that accounts for both the employed workers and the unemployed workers.

The results of the selection (employment) equation are presented in the first two columns of Table 4. The dependent variable indicates whether respondents are currently employed or not. The results from the estimation of the employment equation are in line with the existing literature and are not discussed here, since the focus of the current study is on underemployment and its relationship with Local Employment Dynamics. ${ }^{13}$

\section{TABLE 4. Determinants of Employment and Underemployment (bivariate probit model with sample selection)}

\begin{tabular}{|c|c|c|c|c|}
\hline \multirow[b]{2}{*}{ Variables } & \multicolumn{2}{|c|}{$\begin{array}{l}\text { Employment Equation } \\
\text { (selection equation) }\end{array}$} & \multicolumn{2}{|c|}{$\begin{array}{l}\text { Underemployment Equation } \\
\text { (main equation) }\end{array}$} \\
\hline & Coefficient & Std. Error & Coefficient & Std. Error \\
\hline Married & $0.108^{* * *}$ & 0.023 & $-0.170^{* * *}$ & 0.026 \\
\hline Female & $-0.217^{* * *}$ & 0.036 & $0.201^{* * *}$ & 0.040 \\
\hline Age & $-0.048^{* * *}$ & 0.001 & $0.021^{* * *}$ & 0.004 \\
\hline Education & $0.177^{* * *}$ & 0.007 & $-0.123^{* * *}$ & 0.012 \\
\hline Afro-American & $-0.152^{* * *}$ & 0.026 & $0.251^{* * *}$ & 0.030 \\
\hline Local UnderE & 1.321 & 2.084 & $20.331^{* * *}$ & 3.110 \\
\hline Turnover & $-6.515^{* * *}$ & 0.420 & $2.828^{* * *}$ & 0.720 \\
\hline Area Worker Earnings & $0.0002^{* * *}$ & 0.000 & $-0.0001^{* *}$ & 0.000 \\
\hline Unemployment & $-2.462^{* * *}$ & 0.654 & & \\
\hline Constant & $2.385^{* * *}$ & 0.157 & $-1.251^{* * *}$ & 0.172 \\
\hline Number of observations & 18,148 & & & \\
\hline Log Likelihood & -14485.1 & & & \\
\hline Correlation Coefficient $^{1}$ & $-.8378^{* * *}$ & .0780 & & \\
\hline
\end{tabular}

\footnotetext{
${ }^{13}$ Our sample of interest is the underemployed population. By definition this is a subsample of the employed labor force. We account for the characteristics of the unemployed, and we do not abstract the selection process of who chooses to be employed versus those choosing or forced to be out of the labor force.
} 
The results of the main (underemployment) equation are presented in the last two columns of Table 4. The dependent variable indicates whether respondents are underemployed or not. The probability that workers think they are being underemployed increases with their age. This can be explained by a series of factors such as the demand for job growth, improving worker productivity, or changing job attributes. The discouraged worker hypothesis may also play a role, in the sense that workers with poor employment prospects, such as older people, might have lower employment ambitions. In addition, younger employees are likely to be more motivated to find the jobs that are better suited to their education, skills, and training.

Women's labor force participation tends to be considerably lower than that for men. In the United States in 2000, 54 percent of females were employed versus 65.8 percent of males. ${ }^{14}$ While many microeconomic approaches to female labor supply emphasize personal and household characteristics as determinants of labor supply, macroeconomic approaches tend to stress labor market conditions external to the individual (van Ham and Büchel, 2006; Pratt and Hanson, 1991; van Ham et al., 2001). In particular, these latter studies discuss the constraints women face in the labor market related to space and time because of their greater domestic workload and household responsibilities as well as limited child-care options, all of which raise their reservation wage, sometimes above levels that is suggested by their available human capital. A higher reservation wage, in turn, necessarily limits a woman's desire to exploit many employment opportunities. Moreover, combined with the lower-than-average area female labor force participation rate, which may suggest regional cultural stigma militating against female labor market participation, we should expect that women will have a higher probability of being underemployed than men. The estimation results confirm this expectation. The coefficient for female is positive and significant at the 1 percent level.

Married workers are less likely to be underemployed than non-married workers, regardless of sex or gender. Several factors might contribute to this including a higher degree of motivation to maximize income, which in turn requires or ensures a better match between married workers' jobs and their skills, experience, training or education. This motivation could be driven by the size of the household and the number of dependents. Our survey does not ask respondents about children or dependents but it collects data on the number of people over 18years old living in the household. For married couples, the average number of people over 18 is 2.13 while it is 1.43 for non-married people. For about 30 percent of married couples, only one of the partners is employed. ${ }^{15}$ In our sample, married workers are more likely to say that their jobs fit well with their education, skills, and training, whereas unmarried workers say more often that they are qualified for a better job than they currently have. Married workers also report searching less for a better job than non-married workers.

As expected, the probability of being underemployed decreases with higher levels of education. This concurs with Becker's (1962) seminal exposition of human capital theory. We might also expect that higher education achievement provides workers with a greater ability to find a job that suits their education, skills, and training and then also to hold on to such a job

\footnotetext{
${ }^{14}$ For the state of Alabama, 49 percent of females 16 years and over were employed versus 63 percent of males, a 14 percentage point difference (U.S. Census Bureau, Census 2000). Numbers from our sample for the year 2004 and 2005 were notably different with 45.3 percent of women employed versus 59.0 percent for men.

${ }^{15}$ For married couples with only one partner working, the average number of people over 18 years of age living in the household is 2.05 with a standard deviation of .39 .
} 
once it is obtained. A better job match clearly should reduce the likelihood that a worker would feel underemployed.

IHEP (1998) examines the benefits associated with education, and in particular with higher education. Among these benefits are higher salaries and benefits for workers, better employment opportunities, but also social benefits such as increased personal status or improved quality of life. Thus, these nonpecuniary benefits of greater education achievement also should bolster a worker's propensity to lower their perception of being underemployed. For our categorical educational variable, the coefficient estimate is negative and significant at the 1 percent level.

Underemployment is unevenly distributed among ethnic groups. As expected, minority workers (in our case specifically African-Americans and Hispanics) are more adversely affected by underemployment than are equivalently white workers with otherwise similar characteristics. In our sample, 32.2 percent of African-American and Hispanic workers are underemployed compared to 22.3 percent of white workers. The differential is even greater for AfricanAmerican workers alone, a group for which almost 34 percent are underemployed. Jensen, Findeis, and Wang (2000) also find a substantial black-white underemployment differential, but also note that it declined from 1968 to 1998 in U.S. South, while the Hispanic-white differential grew. For our two-year study period, we find that the underemployment gap increased for both minority groups. That is, while underemployment increased for all workers in the State of Alabama during the period; both African-American and Hispanic workers were adversely affected more heavily and saw their underemployment rate increase relatively more than white workers. A factor that may well explain the broadening underemployment levels for minorities is the education achievement. Table 5 shows that among Alabamans aged 25 years and over, whites tend to have somewhat higher educational attainment compared to blacks. This difference in educational attainment clearly can explain some of the higher share of underemployed among Alabama's African-American workers.

To sum up, the sign of the estimated coefficients for minorities was positive and significant at the 1 percent level, and, hence, met expectations. Whether or not racial/ethnic/language discrimination is the cause or whether it was generated by some other trait(s) highly correlated with minority status but not explicitly specified in the model cannot be explicitly identified by the present study. Regardless, African-American workers appear to subject to greater underemployment in Alabama than are other ethnic groups.

TABLE 5: Educational Attainment in Alabama for the Population 25 years and over (Black and White Alone)

\begin{tabular}{|c|c|c|c|c|c|c|c|c|}
\hline \multirow[b]{3}{*}{ Total: } & \multicolumn{4}{|c|}{ White } & \multicolumn{4}{|c|}{ Black } \\
\hline & \multicolumn{2}{|c|}{2000 Census } & \multicolumn{2}{|c|}{ 2004-2005 } & \multicolumn{2}{|c|}{2000 Census } & \multicolumn{2}{|c|}{ 2004-2005 } \\
\hline & $2,157,934$ & $100.0 \%$ & 12,954 & $100.0 \%$ & 657,233 & $100.0 \%$ & 3,971 & $100.0 \%$ \\
\hline Some high school or less, no diploma & 316,543 & $14.7 \%$ & 2,033 & $15.7 \%$ & 145,741 & $22.2 \%$ & 913 & $23.0 \%$ \\
\hline High school/GED & 660,059 & $30.6 \%$ & 4,433 & $34.2 \%$ & 200,873 & $30.6 \%$ & 1,499 & $37.7 \%$ \\
\hline Some college, no degree & 449,717 & $20.8 \%$ & 2,146 & $16.6 \%$ & 127,584 & $19.4 \%$ & 548 & $13.8 \%$ \\
\hline College/trade school, associate degree & 115,166 & $5.3 \%$ & 1,265 & $9.8 \%$ & 35,853 & $5.5 \%$ & 366 & $9.2 \%$ \\
\hline Four-year college graduate, bachelor's degree & 293,705 & $13.6 \%$ & 1,936 & $14.9 \%$ & 49,467 & $7.5 \%$ & 423 & $10.7 \%$ \\
\hline Postgraduate/Masters etc. & 163,562 & $7.6 \%$ & 1,141 & $8.8 \%$ & 26,129 & $4.0 \%$ & 222 & $5.6 \%$ \\
\hline
\end{tabular}

Source: The University of Alabama's Center for Business and Economic Research and U.S. Census Bureau. 
Simpson (1992) has shown that a spatial mismatch between workers and jobs can translate into a high regional unemployment rate. In this case, extreme friction of commuting within a labor market causes problems of market clearing within certain pockets of the overall labor market. As a result, some workers (particularly those at the low end of the wage scale) may be extraordinarily spatially myopic and perceive conditions in the local labor market to be poorer than they actually are. In this vein, they might be more satisfied with their current job than they would if they were less spatially myopic and therefore have a lower propensity to feel underemployed. That is, they might perceive the probability of getting a more suitable job to be too relatively low given what they perceive as a high local underemployment rate. We therefore expect worker's propensity to feel underemployed to increase with higher rates of regional underemployment. In our analysis, the coefficient for the county-level rate of underemployment Local UnderE is positive and significant at the 1 percent level.

In our sample, the majority of the underemployed workers (55.3 percent) mentioned the low wages offered for available jobs as the main reason for being underemployed. For this reason, we proxy workers' relative wage offers with their home county's average monthly earnings of employees. Thus, in line with expectations, we observe that the probability of being underemployed decreases with higher county-average monthly earnings. That is, the estimated coefficient for Area Worker Earnings is negative and significant at the 5 percent level.

The last Local Employment Dynamics measure that we study in association with underemployment is job turnover-in our case, the rate at which an employer gains and loses employees in the county where the respondent resides. We expect the turnover rate to be positively associated with underemployment. In particular, as mentioned earlier the literature suggests that turnover is associated with the extent of contingent work in the labor market. That is, it measures the share of area workers who are not employed in a career track but rather in jobs that augment household income as suitable work becomes available. Understandably, such workers likely have low expectations of ever being fully employed. Results from our model indicate that, as expected, the coefficient of Turnover is positive and significant at the 1 percent level.

Overall our empirical evidence suggests that poor local labor conditions, as shown by the Local Employment Dynamics data, increase underemployment. Our two LED measures-Area Worker Earnings and Turnover-coupled with the regional underemployment rate (Local UnderE) lend support to the relatively important role of local labor market conditions in predisposing workers toward a feeling of being underemployed when local labor market conditions are worse than those prevailing elsewhere in the state.

\section{CONCLUSION}

In this paper, we examine the relationships between underemployment and both labor force characteristics and local labor market conditions. We introduce three important innovations. First, we use a new and comprehensive estimate of underemployment with detailed characteristics of the employed, underemployed, and nonworkers. Second, we include in our definition of underemployment a labor productivity growth effect. Most definitions of underemployment (such as the ILO's) omit this important potential cause of underemployment. Workers become underemployed as their productivity rises because, as human capital theory suggests, they are able to work smarter, better, and faster through on-the-job experience. Thus as workers become more experienced at their jobs, they wind up doing the same amount of work 
within less time, slowly finding their job easier to perform. This slow mismatching of ability and job requirements is not counted under the ILO's time-related underemployment concept. Finally, we combine our survey dataset with selected variables from the Local Employment Dynamics dataset from the U.S. Census Bureau. Doing so, we find that poor local labor conditions exaggerate workers' perceptions of underemployment. The LED measures coupled with the regional underemployment rate lend support to the important role of local labor market conditions in predisposing workers to feel underemployed when these same labor market conditions are worsening.

We also examine the association between underemployment and individual characteristics. We find that female and minority groups' workers are more subject to underemployment than male and white workers, suggesting at least some general feelings of discrimination by these groups in this regard. Overall our results suggest that education, age, race, and gender play an important role in creating perceptions of underemployment.

In future research, we plan to analyze causes of the duration and persistence of underemployment. We also hope to uncover spatial trends in Alabama's underemployment rate. In this regard, a third survey is underway, and others are planned for the future. Once these waves of surveys are completed, we intend to develop a nonsurvey approach for estimating underemployment to avoid the high costs of large surveys and, thereby, perhaps to examine underemployment in other areas of the nation and world.

\section{REFERENCES}

Addy, Samuel N., Michaël Bonnal, Hwanseok Choi, Ahmad Ijaz, and Dong-Yop Oh. (2005) Underemployment in Alabama Workforce Investment Advisory Areas. Center for Business and Economic Research, University of Alabama.

. (2005) State of the Alabama Workforce I. Center for Business and Economic Research, University of Alabama.

(2006) State of the Alabama Workforce II. Center for Business and Economic Research, University of Alabama.

Allen, Jim and Rolf van der Velden. (2001) "Educational Mismatches versus Skill Mismatches; Effects on Wages, Job Satisfaction, and On-the-job Search," Oxford Economic Papers, $53,434-452$.

Becker, Gary S. (1962) "Investment in Human Capital: A Theoretical Analysis," Journal of Political Economy, 70, 9-49.

. (1991) A Treatise on the Family. Harvard University Press.

Bertrand, Marianne and Sendhil Mullainathan. (2001) "Do People Mean What They Say? Implications for Subjective Survey Data,” American Economic Review, 91, 67-72.

Bollinger, Christopher R., Paul Coomes, and Mark Berger. (2003) Measuring Underemployment at the County Level. University of Kentucky Center for Poverty Research, Discussion Paper Series No. 2003-08.

Dernburg, Thomas and Kenneth Strand. (1966) "Hidden Unemployment 1953-62: A Quantitative Analysis by Age and Sex," American Economic Review, 56, 71-95. 
Hanson, Susan and Geraldine Pratt. (1991) "Job Search and the Occupational Segregation of Women," Annals of the Association of American Geographers, 81, 229-253.

. (1992) "Dynamic Dependencies: A Geographic Investigation of Local Labor Market," Economic Geography, 68, 373-405.

Heckman, James J. (1979) “Sample Selection Bias as a Specification Error," Econometrica, 47, 153-161.

Hersch, Joni. (1991) "Education Match and Job Match," Review of Economics and Statistics, 73, 140-144.

Immergluck, Daniel. (1998) "Job Proximity and the Urban Employment Problem: Do Suitable Nearby Jobs Improve Neighbourhood Employment Rates?” Urban Studies, 35, 7-23.

International Labor Organization (ILO). (1998) Resolution Concerning the Measurement of Underemployment and Inadequate Employment Situations, adopted by the Sixteenth International Conference of Labour Statisticians. International Labor Organization.

Institute for Higher Education Policy (IHEP). (1998) Reaping the Benefits: Defining the Public and Private Value of Going to College. Washington, DC: Institute for Higher Education Policy.

Jensen, Leif, Jill L. Findeis, and Qiuyan Wang. (2000) "Labor Supply and Underemployment in the Southern United States," Southern Rural Sociology, 16, 96-124.

Jovanovic, Boyan. (1979) "Job Matching and the Theory of Turnover," Journal of Political Economy, 87, 972-990.

Kain, John F. (1968) "Housing Segregation, Negro Employment, and Metropolitan Decentralization," Quarterly Journal of Economics, 82, 175-197.

McQuaid, Ronald W., Malcolm Greig, and John Adams. (2001) "Unemployed Job Seeker Attitudes towards Potential Travel-to-work times," Growth and Change, 32, 355-368.

Mincer, Jacob. (1978) "Family Migration Decisions," Journal of Political Economy, 86, 749773.

Moore, Sean. (2005) Regional Asset Indicators: Tapping the Skills Surplus in Rural America. Center for the Study of Rural America, Federal Reserve Bank of Kansas City.

Nebraska Workforce Development (NWD). (2002) Nebraska Underemployment Study: A Comparative Analysis, 1992-2000. Nebraska Workforce Development, Department of Labor, Labor Market Information Center.

Pratt, Geraldine and Susan Hanson. (1991) "Time, Space, and the Occupational Segregation of Women: A Critique of Human Capital Theory," Geoforum, 22, 149-157.

Renaud, Bertrand and Duc-Tu Phan. (1975) "Regional Labor Force Participation and the Discouraged Worker Hypothesis: Some Empirical Evidence," Annals of Regional Science, 9, 9-20.

Sattinger, Michael. (1993) "Assignment Model of the Distribution of Earnings," Journal of Economic Literature, 31, 851-880. 
Schaeffer, Peter. (1985) "Human Capital Accumulation and Job Mobility," Journal of Regional Science, 25, 103-114.

Simpson, Wayne. (1992) Urban Structure and the Labor Market: Worker Mobility, Commuting and Underemployment in Cities. Clarendon: Oxford, U.K.

StataCorp. (2007) Stata Statistical Software: Release 10. College Station, TX.

Van der Lippe, Tanja and Liset van Dijk. (2002) "Comparative Research on Women's Employment," Annual Review of Sociology, 28, 221-241.

Van de Ven, Wynand P.M.M. and Bernard M. S. van Pragg. (1981) "The Demand for Deductibles in Private Health Insurance: A Probit Model with Sample Selection," Journal of Econometrics, 17, 229-252.

Van Ham, Maarten and Felix Büchel. (2006) "Unwilling or Unable? Spatial and Socio-economic Restrictions on Female's Labour Market Access," Regional Studies, 40, 345-357.

Van Ham, Maarten, Clara H. Mulder, and Pieter Hooimeijer. (2001) "Local Underemployment and the Discouraged Worker Effect," Urban Studies, 38, 1733-1751. 